\section{IJßER}

ISSN: 2149-5939
International Journal of Social Sciences and Education Research

Online, http://dergipark.gov.tr/ijsser

Volume: 2(3), 2016

\title{
An investigation into the mobbing levels of the personnel working at pro- vincial directorate of youth welfare and sports and evaluation of organiza- tional commitment ${ }^{1}$
}

\author{
Emre Belli $^{2} \quad$ Nurcan Demirel ${ }^{2}$
}

Received Date: 09 / 05 / $2016 \quad$ Accepted Date: 13 / 08 / 2016

\begin{abstract}
The aim of the present study is to determine the mobbing levels of personnel working at Provincial Directorate of Youth Welfare and Sports and to investigate the relationship between mobbing and the organizational commitment. The sample of the study included 235 personnel working at Provincial Directorates of Youth Welfare and Sports in cities in Eastern Anatolia region including Elazı̆g, Erzurum, Erzincan, Muş, Kars, Bingöl, Malatya and A ̈rrl. In terms of data collection, 'The Mobbing Scale' developed by Öztürk et al. which consists of 68 items was used in order to determine the mobbing levels of the participants. Additionally, in order to measure the organizational commitment of personnel, 'the Organizational Commitment' scale developed by Meyer and Allen which consists of 18 items was used in the study. It was based on $(p<0,05)$ significant level. Data analysis included frequency analysis to examine the demographic information of participants, independent samples t-test to determine the mobbing level in terms of gender, marital status, status and position and one-way ANOVA to compare the mobbing levels in terms of income, age, seniority, education, jobs in institutions and city. Moreover, correlation analysis was conducted in order to measure the relationship between organizational commitment and mobbing. The results of the study indicated that there was a statistically significant negative correlation between organizational commitment and mobbing levels $(r=-.716, p<0.05)$.
\end{abstract}

Keywords: Youth Welfare, Mobbing, Organizational Commitment

\section{Introduction}

After Industrial Revolution, with the development of technology, there has been an increase in manufacturing. With this increase in manufacturing, employees have started to see employers as a cog in the wheel. People seen as equal to machines had to work overtime regardless of their personal and psychological health. After a few years, with the advent of the economic depression, despite the exposure of people who do not have social security to non-human treatment, they continued to work so as to win a bread due to economic worries. As time passed, through legal arrangements, labor union and social security institutions, rights of employees were under protection and people for unions have started to become an important factor increasingly.

In today's conditions, as one of the most important departments of developed companies, human resources department is a sign of how important people are for institutions. Performance is the most important point of interest of modern human resources policy.

Performance is the overall measurement of the contribution of employee for the institution that he has worked by using their personal capabilities. Hence, administrative approaches are

\footnotetext{
${ }^{1}$ This research is a part of my PHD dissertation titled as "An Investigation into the Mobbing Levels of the Personnel Working at Provincial Directorate of Youth Welfare and Sports and Evaluation of Organizational",

${ }^{2}$ Atatürk University Sport Science Faculty, Erzurum/TURKEY
} 
Belli, E., Demirel, N. (2016). An investigation into the mobbing levels of the personnel working at provincial directorate of youth welfare and sports and evaluation of organizational commitment. International Journal of Social Sciences and Education Research, 2 (3), 980-990.

rather important in terms of increasing the performance of the employee and conformity to the institution because the employees with high organizational commitment will have a high personal performance. The concept of organizational commitment is an important notion in terms of embracing organizational aims, maintaining the will of staying in institution, participating in organizational management and activities, having a creative innovative stance for organization and an increase in performance on the part of the employees (Eren and Durna, 2005)

Organizational commitment does not mean just seeing the institution that person has worked as a workplace but also means doing his best with devotion, belonging and embracement of the aims, goals, mission and vision of that institution.

Companies should take precautions to maintain their presence in developing rivalry market and the government institutions should also take measures to be able to do their social responsibilities successfully to increase organizational commitment of employees. The most important problem of the organizational commitment is employee's exposure to mobbing behaviours resulting from employer, manager, or colleagues. Mobbing refers to any kind of conscious and systematic psychological pressures felt by the personnel, that is caused by managers, employers and fellow workers in the work place. The English verb mob is the root of the word mobbing which refers to psychological pressure, surrounding, disturbing and gripping and it means gathering, attacking and disturbing. The word has its origin in the word mobile valgus meaning indecisive crowd in Latin (Davenport, et al. 2003).

Due to psychological pressure, it is not a possible result for the personnel to show their real performance. In their studies, Einarsen and his colleagues have found that the reaction of the personnel who is exposed to mobbing, against the process has started with a reduction in performance (Einarsen, et al. 1996).

In the light of these, the aim of the study is to evaluate the mobbing level of personnel working at the most important public institution Provincial Directorate of Youth Welfare and Sports in terms of their demographic features, and to analyse the relation between level of mobbing and organizational commitment and to present suggestions which are both intuitional and personal to reduce the occurrence of mobbing.

\section{Material and methodology}

\subsection{Participants}

The aim of the present study is to determine the mobbing levels of personnel working at Provincial Directorate of Youth Welfare and Sports and to investigate the relationship between mobbing and the organizational commitment.

\subsection{Procedures}

The population of the study included personnel working at Provincial Directorates of Youth Welfare and Sports in Eastern Anatolia region whereas sample of the study included 67 female 168 male personnel (235 in total) working at Provincial Directorate of Youth Welfare and Sports in Eastern Anatolia region in cities including Elazığ, Erzurum, Erzincan, Muş, Kars, Bingöl, Malatya and Ağrı chosen through Simple Random Sampling method. 
Belli, E., Demirel, N. (2016). An investigation into the mobbing levels of the personnel working at provincial directorate of youth welfare and sports and evaluation of organizational commitment. International Journal of Social Sciences and Education Research, 2 (3), 980-990.

\subsection{Measures}

In this study, the Mobbing Scale developed by Öztürk et al. (2007) which consists of 68 items was used in order to determine the mobbing levels of the personnel. The questionnaire is a Likerttype scale ranging from strongly agree 5 points, agree 4 points, neutral 3 points, disagree 2 point, to strongly disagree 1 point. The scale was measured based on 68-340 score interval. Having a score higher than 204 points in the scale means there is an occurrence of mobbing and having a score below 204 means there is no mobbing (Öztürk, et al. 2007).

In order to measure the organizational commitment of personnel, 'the Organizational Commitment' scale developed by Meyer and Allen which consists of 18 items was used in the study. The mean of total points taken from scale shows the level of organizational commitment of participants (Meyer and Allen, 1991).

\subsection{Analysis}

Frequency analysis was carried out to examine the demographic information of participants and independent samples t-tests were run to determine the mobbing level in terms of gender, marital status, status and position and lastly one-way ANOVA was performed to compare the mobbing levels in terms of income, age, seniority, education, jobs in institutions and city. Moreover, Tukey test was conducted to determine from which group the difference stems. To determine the mean scores of participants took from mobbing and organizational commitment scale, descriptive statistics was conducted and correlation analysis was performed to measure the relationship between organizational commitment and mobbing. For data analysis, SPSS 16,0 was used and the significance level was accepted to be $(\mathrm{p}<0,05)$.

\subsection{Results}

As it is displayed in Table 1, it was revealed that $28.5 \%$ of the whole group were females and males were comprised of $\% 71.5$ considering the distribution of participants in terms of gender. As for age, $\% 32.8$ of participants were between 18-25, \% 13.2 were between 26-32, \% 28.1 were between $33-40, \% 12.8$ were between $41-47$ and \% 13.2 were between 48 and over.

As for the distribution of participants in terms of cities, \%20.4 of the participants had their jobs in Erzurum, \% 10.2 in Elazığ, \% 16.2 in Malatya, \% 9.4 in Erzincan, \% 14.9 in Bingöl, \% 8.9 in Ağrı, \% 10.2 in Muş and \% 9.8 were working in Kars.

Considering their marital status, $\% 59.1$ of whole participants were married, $\% 40.9$ were single. As for their jobs, $\% 37.4$ were officer, $\% 21.3$ of them were trainer, $\% 20$ of them were worker, $\% 13.2$ ' were Sports Educationist and \% 8.1 of them were manager.

In terms of year of seniority, \% 35.7 of the whole participants had 1 to 5 year, $\% 20.9$ had experience ranging from 6 to 10 years, $\% 21.3$ of them had 11 to 15 years of experience, $\% 22.1$ of them were between 16 years and above. As for income anlysis, $\% 8.1$ of the participants had 0-850 Turkish liras, $\% 20.9$ with income of 851-1500 Turkish liras, \% 60.4 with 1501-2500 Turkish liras income, and \% 10.6 of the participants had income of 2501-4000 Turkish liras.

Lastly, in terms of educational background of the participants, $\% 4.3$ of them were the graduates of primary school, \% 19.1 had high school degree, $\% 13.2$ of them had associate degree, $\%$ 54 had Bachelor degree, and \% 9.4 had postgraduate degree. 
Belli, E., Demirel, N. (2016). An investigation into the mobbing levels of the personnel working at provincial directorate of youth welfare and sports and evaluation of organizational commitment. International Journal of Social Sciences and Education Research, 2 (3), 980-990.

Table 1. Analysis of participants according to demographic features

\begin{tabular}{|c|c|c|}
\hline Gender & $\mathbf{N}$ & $\%$ \\
\hline Female & 67 & 28.5 \\
\hline Male & 168 & 71.5 \\
\hline Age & $\mathbf{N}$ & $\%$ \\
\hline 18-25 Age & 77 & 32,8 \\
\hline 26-32 Age & 31 & 13,2 \\
\hline 33-40 Age & 66 & 28,1 \\
\hline 41-47 Age & 30 & 12,8 \\
\hline 48 Age and above & 31 & 13,2 \\
\hline City & $\mathbf{N}$ & $\%$ \\
\hline Erzurum & 48 & 20,4 \\
\hline Elazı ̆ & 24 & 10,2 \\
\hline Malatya & 38 & 16,2 \\
\hline Erzincan & 22 & 9,4 \\
\hline Bingöl & 35 & 14,9 \\
\hline Ăgrn & 21 & 8,9 \\
\hline Muş & 24 & 10,2 \\
\hline Kars & 23 & 9,8 \\
\hline Marital Status & $\mathbf{N}$ & $\%$ \\
\hline Married & 139 & 59.1 \\
\hline Single & 96 & 40.9 \\
\hline Position & $\mathbf{N}$ & $\%$ \\
\hline Officer & 88 & 37,4 \\
\hline Trainer & 50 & 21,3 \\
\hline Worker & 47 & 20,0 \\
\hline Sport Educationist & 31 & 13,2 \\
\hline Manager & 19 & 8,1 \\
\hline Year of Seniority & $\%$ & $\mathbf{N}$ \\
\hline $1-5$ year & 84 & 35.7 \\
\hline 6-10 year & 49 & 20.9 \\
\hline $11-15$ year & 50 & 21.3 \\
\hline 16 year and above & 52 & 22.1 \\
\hline Income & $\%$ & $\mathbf{N}$ \\
\hline $0-850 \mathrm{TL}$ & 19 & 8.1 \\
\hline $851-1500 \mathrm{TL}$ & 49 & 20.9 \\
\hline $1501-2500 \mathrm{TL}$ & 142 & 60.4 \\
\hline $2501-4000 \mathrm{TL}$ & 25 & 10.6 \\
\hline Education & $\%$ & $\mathbf{N}$ \\
\hline Primary Education & 10 & 4,3 \\
\hline High School & 45 & 19,1 \\
\hline Associate Degree & 31 & 13,2 \\
\hline Bachelor's Degree & 127 & 54,0 \\
\hline Postgraduate & 22 & 9,4 \\
\hline Total & 235 & 100 \\
\hline
\end{tabular}


Belli, E., Demirel, N. (2016). An investigation into the mobbing levels of the personnel working at provincial directorate of youth welfare and sports and evaluation of organizational commitment. International Journal of Social Sciences and Education Research, 2 (3), 980-990.

Table 2. Comparison of level of mobbing of participants depending on gender

\begin{tabular}{llllll}
\hline Gender & N & Mean & St.Dev. & t & P \\
\hline Female & 67 & 195.19 & 65.691 & -2.394 & $.017^{*}$ \\
Male & 168 & 217.88 & 65.531 & & \\
\hline
\end{tabular}

$*(\mathrm{p}<0,05)$

Based on the findings of data analysis, there was no statistically significant difference between female and male personnel in terms of mobbing levels of participants depending on gender. $(\mathrm{p}=.017)$.

Considering this finding, more specifically, male personnel had a higher level of mobbing $(X=217.88 \pm 65.531)$ compared to females $(X=195.19 \pm 65.529)$. Furthermore, male personnel having score of over 204 shows that other than having higher mean scores than women, males are exposed to mobbing. Female personnel were found to have not despite the data which is close to mobbing mean on the part of female personnel, generally, there is no occurrence of mobbing.

Table 3. Comparison of mobbing levels of participants depending on status at the institution

\begin{tabular}{llllll}
\hline Status & N & Mean & St.Dev. & t & p \\
\hline Manager & 35 & 230.23 & 69.177 & 1.831 & .068 \\
Personnel & 200 & 208.12 & 65.330 & & \\
\hline$*(\mathrm{p}<0,05)$ & & & & &
\end{tabular}

Based on data analysis, it was revealed that there was not a statistically significant difference in mobbing levels of participants depending on their status $(p>0,05)$.

Although there is not a statistically significant difference, it was found out that both manager $(X=230.23 \pm 69.177)$ and personnel $(X=208.12 \pm 65.330)$ were above mobbing mean score. Moreover, it was also revealed that the people who worked as managers had a higher level of mobbing compared to those working as personnel.

Table 4. Comparison of mobbing levels depending on education of participants

\begin{tabular}{llllll}
\hline \multicolumn{1}{c}{ Education } & N & Mean & St. Dev. & f & p \\
\hline Primary School & 10 & 204.33 & 65.235 & & \\
High School & 45 & 220.93 & 64,646 & & \\
Associate Degree & 31 & 194.19 & 64.745 & 3.024 & $.019^{*}$ \\
Bachelor Degree & 127 & 246.90 & 68.753 & & \\
Postgraduate Degree & 22 & 240.86 & 64.333 & & \\
\hline$*(p<0,05)$ & & & &
\end{tabular}

When data was analysed, it was found out that mobbing was observed across educational status including bachelor degree, postgraduate, high school, and primary school and there was a statistically significant difference in mobbing levels of participants depending on their educational background $(\mathrm{p}=.019)$. Table 5 below demonstrates the results of differences among participants and the source of differences. 
Belli, E., Demirel, N. (2016). An investigation into the mobbing levels of the personnel working at provincial directorate of youth welfare and sports and evaluation of organizational commitment. International Journal of Social Sciences and Education Research, 2 (3), 980-990.

According to multiple comparison test results, there were statistically significant differences in educational status $(\mathrm{p}<0.05)$ between personnel of primary school graduate and personnel having BA Degree $(p=.011)$, between Primary School and Postgraduate Degree $(p=.034)$, between Associate Degree and BA Degree ( $p=.001)$, Associate Degree and Postgraduate degree $(p=.018)$.

Table 5. Multiple comparison results of mobbing levels of participants depending on educational background (Post Hoc-Tukey Test)

\begin{tabular}{llcc}
\hline \multirow{2}{*}{ Comparison } & & Difference & $\begin{array}{c}\text { Significance } \\
\text { Level }\end{array}$ \\
\hline Primary School & High School & -16.594 & .584 \\
& Associate Degree & 10.145 & .937 \\
& BA Degree & -42.561 & $.011^{*}$ \\
& Postgraduate Degree & -36.525 & $.034^{*}$ \\
\hline High School & Primary School & 16.594 & .584 \\
& Associate Degree & 26.739 & .400 \\
& Bachelor Degree & -25.966 & .785 \\
& Postgraduate Degree & -19.930 & .765 \\
\hline Associate Degree & Primary School & -10.145 & .937 \\
& High School & -26.739 & .400 \\
& BA Degree & -52.706 & $.001^{*}$ \\
& Postgraduate & -46.670 & $.018^{*}$ \\
\hline Bachelor Degree & Primary School & 42.561 & $.011^{*}$ \\
& High School & 25.966 & .785 \\
& Associate Degree & 52.706 & $.001^{*}$ \\
& Postgraduate Degree & 6.036 & .999 \\
\hline Post. Degree & Primary School & 36.525 & $.034^{*}$ \\
& High School & 19.930 & .765 \\
& Associate Degree & 46.670 & $.018^{*}$ \\
& BA Degree & -6.036 & .999 \\
\hline
\end{tabular}

$$
*(\mathrm{p}<0,05)
$$

According to multiple comparison test results, there were statistically significant differences in educational status $(\mathrm{p}<0.05)$ between personnel of primary school graduate and personnel having BA Degree $(\mathrm{p}=.011)$, between Primary School and Postgraduate Degree $(\mathrm{p}=.034)$, between Associate Degree and BA Degree ( $\mathrm{p}=.001)$, Associate Degree and Postgraduate degree $(\mathrm{p}=.018)$.

Based on this finding, it was observed that the personnel who have BA Degree $(X=246.90 \pm 68.753)$ and Postgraduate Degree $(X=240.86 \pm 64.333)$ are exposed to mobbing more than the personnel who have graduated from primary school $(X=204.33 \pm 65.235)$ and Associate Degree $(X=194.19 \pm 64.745)$.

Table 6. Comparison of mobbing levels of participants depending on year of seniority

\begin{tabular}{llllll}
\hline Seniority & N & Mean & Std.Dev. & f & p \\
\hline 1-5 Year & 84 & 231.09 & 62.341 & & \\
6-10 Year & 49 & 207.46 & 71,719 & 2.786 & $.042^{*}$ \\
11-15 Year & 50 & 216.28 & 69.636 & & \\
16 Year and Above & 52 & 198.61 & 60.921 & & \\
& & & & & \\
\hline
\end{tabular}

$*(\mathrm{p}<0,05)$ 
Belli, E., Demirel, N. (2016). An investigation into the mobbing levels of the personnel working at provincial directorate of youth welfare and sports and evaluation of organizational commitment. International Journal of Social Sciences and Education Research, 2 (3), 980-990.

Based on the analysis of data, mobbing was observed among the personnel who have 1-5 Year, 6-10 Year and 11-15 Year of seniority and the significance level between mobbing mean and year of seniority of participants was found to be $(\mathrm{p}=.042)$. The multiple comparison test results depending on groups are given in Table 7.

Table 7. The multiple comparison results of mobbing level of participants depending on year of seniority (Post Hoc-Tukey Test)

\begin{tabular}{cccccc}
\hline Seniority & N & Mean & Std.Dev. & f & p \\
\hline 1-5 Year & 84 & 231.09 & 62.341 & & \\
6-10 Year & 49 & 207.46 & 71,719 & 2.786 & $.042^{*}$ \\
11-15 Year & 50 & 216.28 & 69.636 & & \\
16 Year and above & 52 & 198.61 & 60.921 & &
\end{tabular}

$*(\mathrm{p}<0,05)$

According to results of multiple comparison tests, there was not a statistically significant difference between the personnel who have $1-5$ years and +16 years year of seniority $(p=.027)$ at the significance level of $(\mathrm{p}<0.05)$.

Accordingly, it was observed that the personnel who have 1-5 Year of seniority $(\mathrm{X}=231.09 \pm 62.341)$ were exposed to mobbing more than the ones who have 16 Years and above seniority $(X=198.61 \pm 60.921)$.

Table 8 . The mean of mobbing and organizational commitment scale of participants

\begin{tabular}{|c|c|c|c|c|c|c|}
\hline Scale & & $\mathbf{N}$ & Min. & Max. & Mean & Std.Deviation \\
\hline $\begin{array}{l}\text { Organizational } \\
\text { mitment }\end{array}$ & Com- & 235 & 1 & 5 & 3.27 & .587 \\
\hline Mobbing & & 235 & 68 & 340 & 211.41 & 66.236 \\
\hline
\end{tabular}

$*(\mathrm{p}<0,05)$

Based on the analysis of data, it was found out that generally participants were exposed to mobbing $(X=211.41 \pm .587)$ and had an average level of organizational commitment against the instutition $(\mathrm{X}=3.27 \pm .587)$.

Table 9. Correlation results in terms of the relationship between mobbing level and organizational commitment of participants

\begin{tabular}{|c|c|c|c|c|}
\hline & & & $\begin{array}{l}\text { Organizational Com- } \\
\text { mitment }\end{array}$ & Mobbing \\
\hline \multirow{3}{*}{$\begin{array}{l}\text { Organizational } \\
\text { mitment }\end{array}$} & \multirow{3}{*}{ Com- } & Pearson Correlation & 1000 & $-.716 * *$ \\
\hline & & $\mathrm{P}$ & & .000 \\
\hline & & $\mathrm{N}$ & 235 & 235 \\
\hline \multirow{3}{*}{ Mobbing } & & Pearson Correlation &,$- 716 * *$ & 1000 \\
\hline & & $\mathrm{P}$ &, 000 & \\
\hline & & $\mathrm{N}$ & 235 & 235 \\
\hline
\end{tabular}

*(p<0,05)

According to findings of the study, it was observed that there was a negative correlation between organizational commitment level and mobbing level of participants $(r=-.716, p<0.05)$. 
Belli, E., Demirel, N. (2016). An investigation into the mobbing levels of the personnel working at provincial directorate of youth welfare and sports and evaluation of organizational commitment. International Journal of Social Sciences and Education Research, 2 (3), 980-990.

Based on this, it can be said that when the level of exposure to mobbing increased, the organizational commitment levels decreased.

\section{Discussion}

Mobbing levels of personnel was analysed based on gender variable and there was a correlation between the females and males. Based on this finding, it was seen that male personnel had a higher level of mobbing $(X=217.88 \pm 65.531)$ compared to female personnel $(X=195.19 \pm 65.529)$

These findings can result from the fact that males see the job as a life style, consider job as a tool for responsibilities like breadwinning for the family and put the job at the center of his life due to the more dominant character of males than females. That sort of individual can exaggerate the problem at work inwardly by overestimating it and combining it with future anxiety. It can be concluded that the situation was much more serious when we take into account the possibilities of the differences in mobbing levels of males, the fear of showing themselves as having weak personality due to the role in our societal structure, and their inability to express their feelings.

Alkan (2011) in his study in which he analysed Physical Education Department teachers found out that males were more exposed to mobbing but did not find any significant difference. In addition, in their study, Hoel, et al. (2001) concluded that males working especially in worker and officer group were more exposed to mobbing than females. Hoel and Cooper (2000) found that males were more exposed to negative attitudes than females in the study that they carried out. These results support the findings that we found.

In contrast to our findings, Arsan (2008) in his study of mobbing at workplace found out that the occurrence of exposure to mobbing differed depending on gender, and females were more exposed to mobbing than males. In a study conducted by Zapf (1999) it was revealed that among the individuals who said that they were exposed to mobbing, \% 75.3' of them were females and $\% 24.7$ of them were males. These findings contradict with the findings that we found.

In our study, mobbing was observed among both managers and personnel, and there was not a statistically significant difference between these two groups in terms of their mobbing levels. Despite this finding, it is one of the interesting findings that the personnel who work as manager $(\mathrm{X}=230.23 \pm 69.177)$ had quite high mean scores than the ones who work as personnel $(X=208.12 \pm 65.330)$. Salin (2001) in his study found that personnel were more exposed to mobbing than managers. The author interpreted this result as in the following way: Managers cause more mobbing on personnel by making use of the authority that they have. It was understood that generally managers are less exposed to mobbing based on the findings of many research focusing on the comparison between intimidation and status in many private companies. It was also found out that $\% 83$ of mobbing treatments observed in the \% 63 workplaces in England were due to the managers. (Vandekerckhove, et al., Commers, 2003). These findings contradict with the findings that we found.

Unlike these findings, in our study, the participants who are more exposed to mobbing were the people who work as managers. It is quite expected when we think about the fact that since the participants in our study were the personnel working at public institution and there might be possible political pressure and government authority. 
Belli, E., Demirel, N. (2016). An investigation into the mobbing levels of the personnel working at provincial directorate of youth welfare and sports and evaluation of organizational commitment. International Journal of Social Sciences and Education Research, 2 (3), 980-990.

In our study, when mobbing levels of personnel were considered depending upon the educational background, mobbing was observed in terms of educational status including BA, Postgraduate Degree, high school, primary school and there was a correlation between educational status of participants and mobbing mean scores.

One of the most important findings was that the most exposure to mobbing was among the $\mathrm{BA}(\mathrm{X}=246.90 \pm 68.753)$ and Postgraduate Degree participants $(X=240.86 \pm 64.333)$. Increase in the perception of mobbing and the increase in the level of education can be explained as in the following way: the personnel who have a high level of education have more developed capabilities of working independently, making decisions on behalf of manager, criticizing with managerial and personal responsibility. These people might have had a more easily offended stance due to critism of higher level based on their status.

Yavuz (2007) observed that the attitudes of the personnel working at Süleyman Demirel University at the Medical Faculty Hospital towards perception of mobbing differed depending on educational background. According to Yavuz (2007), as the level of education increased, there was a linear increase in the level of feeling of mobbing. This finding supports what we have found.

Saraç (2011) studied upon the effect of mobbing on personnel at workplace and found out that there was no correlation between level of education and concept of mobbing. Arisoy, (2011) has not found any correlation between mobbing and education variable in his study on the factors affecting mobbing of nurses working at Isparta, Antalya and Burdur cities. These findings contradict with the findings of our research.

According to results of multiple comparison tests, there was a significant correlation between the personnel having 1-5 years and 16 years and above seniority $(\mathrm{p}=.027)$. Based on this finding, it was seen that the personnel who have 1-5 years $(X=231.09 \pm 62.341)$ of seniority were more exposed to mobbing than the ones who had $16+$ years of seniority $(X=198.61 \pm 60.921)$.

Based on the findings that we have obtained from the data analysis in our study, we can conclude that in the institution where we carried out our study, as the year of seniority passes, there is a decrease in mobbing practise and feeling of it. This can result from the fact that either personnel might have been more experienced about dealing with mobbing as the year of seniority in the workplace changes, or they were more respected by other people in the institution for their age and year of seniority. High level of intimidation of personnel who have entered to a new social environment and who are at the beginning of seniority with 1-5 years can stem from difficulties experienced in the adaptation process to working conditions and colleagues of theirs and perception of colleagues as strangers in the adaptation process. Hence some new personnel who does not know work ethics and operation principles of fellow workers can consider any responsibility that is expected from him as unnecessary stuff and may find quite natural utterance as insulting. This finding has to do with the person himself or result from mobbing practise against this newcomer by other people in the institution in the form of saddling him with the task of their own or ignoring him.

Köse (2010) has not found any significant difference between mobbing and year of seniority in his study focusing on doctors and nurses working at Gazi University hospital. This finding contradicts with the finding that we have found. 
Belli, E., Demirel, N. (2016). An investigation into the mobbing levels of the personnel working at provincial directorate of youth welfare and sports and evaluation of organizational commitment. International Journal of Social Sciences and Education Research, 2 (3), 980-990.

In the current study, it was revealed that there was a negative correlation between organizational commitment and mobbing level of participants $(r=-.716, p<0.01)$. Based on this result, as the level of exposure to mobbing of personnel increased, organizational commitment decreased. This means that the personnel who is faced with mobbing and pressure in the institution had a lower level of organizational commitment against the institution. Atalay (2010) has found a negative correlation between organizational commitment and mobbing in the study conducted on public sector. Karcığlu and Çelik (2012) have found a negative correlation between organizational commitment and mobbing in their research on the effect of mobbing on organizational commitment. In another study, Özler et al. (2008) investigated the link between organizational commitment and mobbing and revealed a negative correlation. These findings support the findings that we have found.

\section{Conclusions}

Considering the findings of the current research, as for the implications, the following suggestions are provided for the people who are exposed to mobbing. Prior to this, what has happened must be understood thoroughly and evaluated carefully. If the person that you think has mobbing effect on you is not a authority in the management, you can get help from management. Another job which has similar or much better working conditions could be considered. Legal rights can be applied benefiting from constitution which is getting more serious with the latest legal regulations about mobbing. If the person does not think about following such a legal way and does not want to quit the job, this kind of person can get assistance from the people around their environment or psychological support. The person must not isolate himself from the society and should give up the victim mentality. Moreover, such a person can keep himself aside from the feeling of mobbing by tackling any kind of new hobby or interest.

As for the institutional suggestions for workplace which is exposed to mobbing, mobbing must be accepted as a institutional problem and behaviours signalling mobbing must be clearly stated. The truth that mobbing will take place both horizontally and vertically in hierarchical order must be taken into consideration and necessary procedures must be prepared for all personnel. Serious managerial disciplinary penalties must be given against the practise of mobbing. Personal growth programs such as courses, seminars, conferences, panels, and symposiums can be arranged for the personnel to help them solve the problems that they face at workplace. Action must be taken in confidentiality and complaint guidelines about mobbing should be formed. Complaints must be assessed by an independent control unit composed separately from institutions personnel.

Consequently, mobbing as one of the most important factors which threat human health and thus and the performance must be detected and eliminated as soon as possible.

\section{References}

Alkan E. (2011). Yıldırma (Mobbing) Davranışlarının Beden Eğitim ve Spor Öğretmenlerinin Tükenmişliği Üzerine Etkisi. Sosyal Bilimler Enstitüsü, Beden eğitimi ve Spor Anabilim Anabilim Dalı. Yüksek Lisans Tezi, Balıkesir: Balıkesir Üniversitesi.

Arısoy A. (2011). Mobbingi Ortaya Çıkaran Faktörler: Isparta- Antalya Burdur'da Sağlık Sektöründe Hemşireler Üzerine Çalışma, Süleyman Demirel Üniversitesi, Sosyal Bilimler Enstitüsü, Çalışma Ekonomisi ve Endüstri İlişkileri Anabilim Dalı. Yüksek Lisans Tezi, Isparta: Süleyman Demirel Üniversitesi. 
Belli, E., Demirel, N. (2016). An investigation into the mobbing levels of the personnel working at provincial directorate of youth welfare and sports and evaluation of organizational commitment. International Journal of Social Sciences and Education Research, 2 (3), 980-990.

Arsan T. (2008). İs Yerinde Psikolojik Taciz Olgusu: Tacizcilerin Kişilik Özellikleri Üzerine Bir Çalışma. Sosyal Bilimler Enstitüsü, Yönetim ve Çalışma Ekonomisi ve Endüstri İlişkileri Anabilim Dalı. Yüksek Lisans Tezi, İstanbul: Marmara Üniversitesi.

Atalay İ. (2010). Mobbing'in Örgütsel Bağl1lık Üzerindeki Etkisi ‘'Kamu Sektöründen Bir Örnek'. Sosyal Bilimler Enstitüsü, İşletme Anabilim Dalı. Yüksek Lisans Tezi, Ankara: Atılım Üniversitesi.

Davenport N, Schwartz RD, Ellıtt GP. (2003). Mobbing: İşyerlerinde Duygusal Taciz, (Çev: Osman Cem Önortay), İstanbul, Sistem Yayıncilık.

Einarsen S, Rakness BI, Matthiesen SBM, Hellesoy OH. (1996). Bullying at work and its relationships with health complaints- moderating effects of social support and personality. Nordisk Psykologi, 48: 116137.

Eren V, Durna U. (2005). Üç bağl1lık unsuru ekseninde örgütsel bağl1lık, Doğuş Üniversitesi Dergisi, 6: 210-219.

Hoel H, Cooper C, Faragher B. (2001). The experience of bullying in great britain: The impact of organizational status. Europen Journal of Work and Organizatioanl Pstchology, 10: 443-465.

Hoel, H. Cooper, C.L. (2000). Destructive conflict and bullying at work, university of manchester, Institute of Science and Technology, Unpublished report, 10: 124-126.

Karcıoğlu F, Çelik HÜ. (2012). Mobbing (yıldırma) ve örgütsel bağlılığa etkisi. Atatürk Üniversitesi İktisadi ve İdari Bilimler Dergisi, 26: 31.

Köse E. (2010). Bir Üniversite Hastanesinde Hekim ve Hemşirelerin Algıladıkları Örgüt Kültürünün Mobbing Davranışlarına Etkisi. Sağlık Bilimleri Enstitüsü, Hemşirelik Anabilim Dalı. Yüksek Lisans Tezi, Ankara: Gazi Üniversitesi.

Meyer JP. Allen NJ. (1991). A three-component conceptualization of organizational commitment. Human Resource Management Review, 1: 61-89.

Özler EG, Atalay GC, Şahin DM. (2008). Mobbing'in örgütsel bağl1lık üzerine etkisini belirlemeye yönelik bir araştırma. Dumlupınar Üniversitesi Sosyal Bilimler Dergisi, 4: 22.

Öztürk H, Yılmaz F, Hindistan S. (2007). Hemşireler İçin mobbing ölçeği ve hemşirelerin yaşadığı mobbing. Hastane Yönetimi,11: 1-2.

Salin D. (2001). Prevelance and forms of bullying among business professionals: a comparison of two different strategies for measuring bullying. European Journal of Work and Organizational Psychology, 10: $425-441$.

Saraç E. (2011). İş Ortamında Psikolojik Tacizin (Mobbing) Çalışanlar Üzerinde Etkileri. Sosyal Bilimler Enstitüsü, İşletme Yönetimi Anabilim Dalı. Yüksek Lisans Tezi, İstanbul: Beykent Üniversitesi.

Vandekerckhove W, Commers MSR. (2003). Downward workplace mobbing: a sign of the times? Journal of Business Ethics 45: Kluwer Academic Publishers. Printed in the Netherland, 61: 41-50.

Yavuz H. (2007). Çalışanlarda Mobbing (Psikolojik Şiddet) Algısını Etkileyen Faktörler: Sdü Tıp Fakültesi Üzerine Bir Araştırma. Sosyal Bilimler Enstitüsü, İşletme Anabilim Dalı. Yüksek Lisans Tezi, Isparta: Süleyman Demirel Üniversitesi.

Zapf D. (1999). Organizational, work group related and personal causes of mobbing/bullying at work. International Journal of Manpower, 20: 70-85. 